\section{Commentary: Virtual education in cardiothoracic surgery: Born out of necessity, enduring influence}

\author{
Marc R. Moon, MD
}

The 100th American Association for Thoracic Surgery (AATS) Annual Meeting in 2020 was not the first time the Annual Meeting has been disrupted by world events. In fact, the first AATS Annual Meeting was held in the midst of the 1918 influenza pandemic, caused by an H1N1 virus that ultimately infected one-third of the world's population. ${ }^{1,2}$ There was no vaccine. There were no antibiotics to treat secondary bacterial infections. Social distancing and other nonpharmaceutical interventions were all that was available, much like today. The AATS survived-as did the world-but not without great cost. It is estimated that 50 million died as a consequence worldwide. The 1918 influenza pandemic did not change the world forever, nor will coronavirus disease 2019 (COVID-19), but until we have conquered this dreadful disease, we must all take measures to protect ourselves and the community at large. ${ }^{3-5}$

Vervoort and colleagues, ${ }^{6}$ a team of esteemed academic cardiothroracic surgical leaders, put together an outstanding article outlining the challenges, benefits, and recommendations for the future of virtual educational offerings. They summarize the pros and cons, ultimately concluding that a hybrid model, with a fully virtual component and smaller in-person component as social protocols will allow, may best serve the global cardiothoracic community. Given the alternative of canceling our national meetings for the next year or 2, it is on us, specifically Dr Dearani and me representing the Society of Thoracic Surgeons (STS) and AATS this year, to make it possible for health care professional to pursue lifelong learning while continuing to advance our

\footnotetext{
From the Division of Cardiothoracic Surgery, Washington University School of Medicine, St Louis, Mo.

Disclosures: Dr Moon is a consultant/advisory board member for Medtronic.

The Journal policy requires editors and reviewers to disclose conflicts of interest and to decline handling or reviewing manuscripts for which they may have a conflict of interest. The editors and reviewers of this article have no conflicts of interest.

Received for publication Aug 24, 2020; revisions received Aug 24, 2020; accepted for publication Aug 25, 2020; available ahead of print Aug 28, 2020.

Address for reprints: Marc R. Moon, MD, Division of Cardiac Surgery, Washington University School of Medicine, 660 S Euclid Ave, Campus Box 8234, St Louis, MO 63110 (E-mail: moonm@wustl.edu).

J Thorac Cardiovasc Surg 2021;161:753-5

$0022-5223 / \$ 36.00$

Copyright (c) 2020 by The American Association for Thoracic Surgery

https://doi.org/10.1016/j.jtcvs.2020.08.079
}

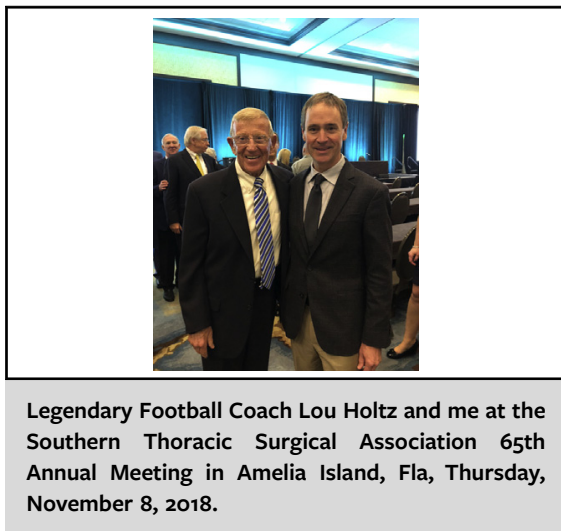

CENTRAL MESSAGE

AATS virtual conferencing was born out of necessity due to travel mandates to combat COVID-19. The success of the Virtual 100th AATS Annual Meeting suggests such an approach may have enduring influence.

scholarly paradigm. This past year, the sudden appearance of the COVID-19 pandemic mandated the AATS turn on a dime to put together the 100th Annual Meeting: A Virtual Experience. $^{7,8}$ As a consequence, we were only able to offer a small percentage of the content we had planned for the in-person meeting in New York City. This coming year, Joe Woo and Vinod Thourani are developing an allencompassing program to include a full complement of abstracts from all disciplines. The intent is to include the majority of AATS members in the program as abstract presenters, discussants, panelists, or invited speakers following the format introduced by David Adams at the 99th Annual Meeting in Toronto. It is easy to be pessimistic given the continually increasing negative news we have received these past few months, but the STS and AATS will survive; I promise. So, let's be careful not to define a new normal prematurely.

The new normal is the state at which society settles following a crisis, but only if it differs from the situation before the crisis began. Robert Heinlein first coined the phrase new normal in his 1966 novel, The Moon is a Harsh Mistress. ${ }^{9}$ Heinlein used it to describe a lunar anarchist society free of authority, a new normal that ironically would ultimately fail. Since spring 2020, Anthony Fauci and 


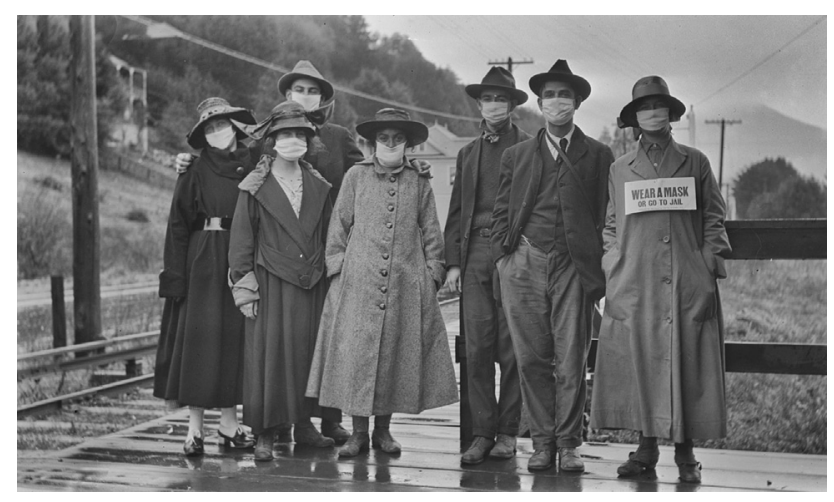

FIGURE 1. Although measures like face masks became a part of daily life during the 1918 influenza pandemic, they did not continue once the pandemic was under control.

others have used the term to describe limiting person-toperson contact with face mask wearing and social distancing. Although these measures became a part of daily life during the 1918 influenza pandemic, the need for such drastic measures did not persist once the pandemic was under control (Figure 1). There was no new normal as a consequence of the 1918 pandemic, despite the lack of a vaccine or any medical therapeutic option, and I feel strongly that there will be no new normal as a consequence of COVID-19.

Frank Spencer, 63rd AATS president, spoke of the importance of attending the AATS Annual Meeting in person. ${ }^{10}$ "You can read the paper later, but at the meeting you can hear and even feel the discussion." An even bigger value he attributed was the opportunity to get acquainted with a diverse group of colleagues. "It's invaluable. I have gotten to know people on a first name basis from each state in the Union and many countries around the world." $\mathrm{He}$ went on the emphasize that conferences like the AATS Annual Meeting play a substantial role, not in the creation of knowledge, but the expansion of knowledge as a reservoir for the cardiothoracic surgical team to exchange ideas. He concluded, "Let's keep it that way."

Some express concern that virtual meetings will not facilitate the appropriate level of inspiration or emotion during the respective organization's presidential address or honored guest speakers. These presentations offer long-term memories for all who attend. I was inspired by Notre Dame Coach Brian Kelly in Baltimore in 2016 describing the characteristics of a great leader, including how leaders should be cognizant of their own strengths and weaknesses. I also intimately remember Toronto 2014 when Rick Pitino described his concept of the One-Day Contract the year after he won the National College Athletic Association National Basketball Championship at the University of Louisville, a contract he effectively broke, leading to his resignation as head coach on October 3, 2017, amidst a scandal in which he was charged with failure to monitor his basketball program. ${ }^{11}$

The messages of many past Honorary Lecturers at all our national and international meetings are timeless. I was not there, but I am sure all those in attendance at the 65th AATS Annual Meeting were moved deeply by Hans Borst's plea to strengthen the bond between European and the American cardiothoracic surgeons in his Honorary Guest Lecture titled, "Hands Across the Ocean" in New Orleans in $1985 .^{12}$ Continued strengthening of international outreach remains an important component of the AATS Strategic Plan today. Thirty-five years later again in New Orleans, Clyde Yancey raised emotions during the Vivien T. Thomas Lecture as Dr Bob (BHig) Higgins guest at the 56th STS Annual Meeting in January 2020. Dr Yancey expounded our checkered past then extolled the benefits of embracing what I like to refer to as diversity without exclusion, also an important component of the AATS Strategic Plan. ${ }^{13}$ My favorite guest lecturer at any meeting was legendary football coach Lou Holtz at the 65th Annual Meeting of the Southern Thoracic Surgical Association (STSA) on Amelia Island, Fla, in 2018. Coach Holtz was STSA President Kevin Accola's invited lecturer. Everyone in the auditorium was on the edge of his or her seat as Coach Holtz described how to build a successful team in the millennial generation based on trust, commitment, and caring. ${ }^{14}$ The only memory that topped it was Dr Accola regaling us with the tale of how the STSA was able to afford such an inspiring, well-remunerated raconteur.

"Lou," Kevin asked his Orlando neighbor, "Do you

believe in free speech?"

“Well, sure I do Kevin. Why do you ask?” responded Coach.

\section{"Because that's what I need for the STSA: A free} speech!"

It was a compelling morning that would have been impossible to replicate in a virtual environment (Figure 2). Ultimately, it all comes down to content. Medical, nursing, and all other health professional boards require us to pursue lifelong learning, and our medical specialty organizations have a responsibility to provide that education.

Potentially the most influential absence from a completely virtual format is the networking opportunities for senior residents to meet the leaders of programs seeking new colleagues to join their practice. Of 50 graduates from the Washington University Thoracic Surgery Residency during my 17-year tenure as program director, nearly $50 \%$ either met their future senior partner or signed the letter of intent at 1 of our major meetings. Just this past year at the STS meeting, I introduced recent graduate Stephen Waterford to my long-time friend. Randy Green who runs the State University of New York Upstate program in 


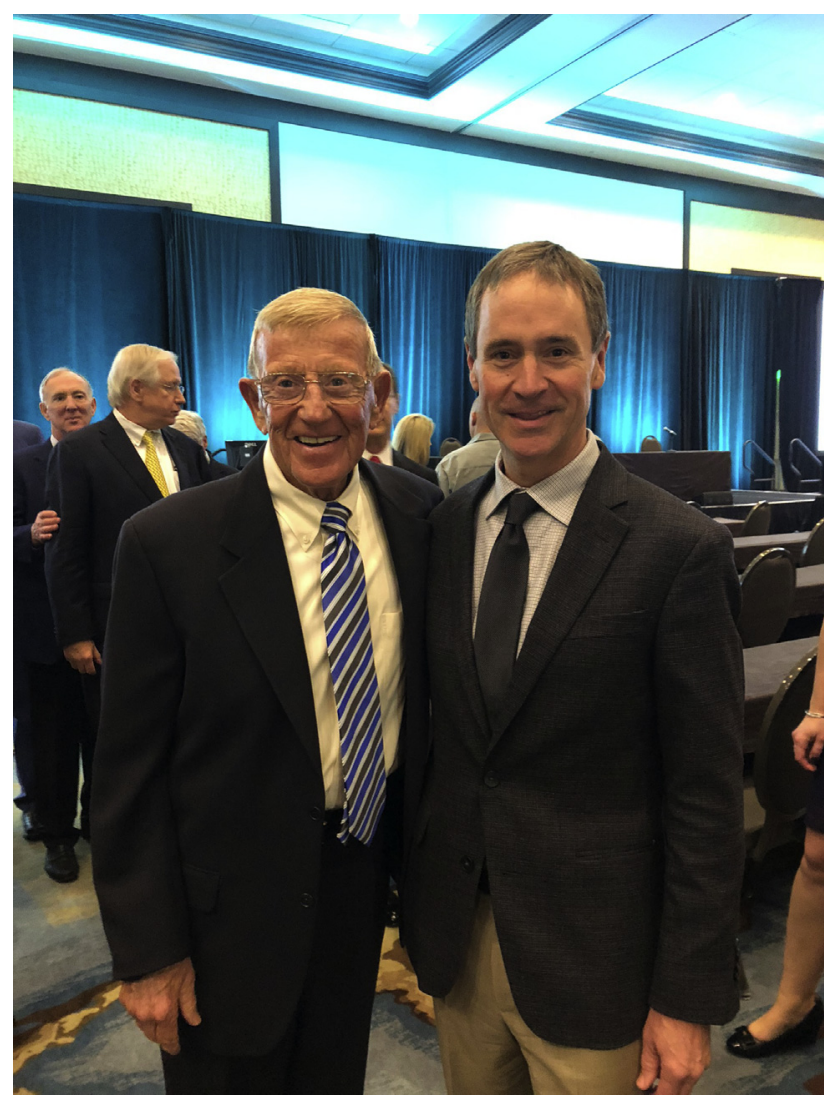

FIGURE 2. The author and legendary football coach Lou Holtz at the 65th Annual Meeting of the Southern Thoracic Surgical Association, on Amelia Island, Fla, in 2018.

Syracuse. Waterford has since joined Green, a win-win for both that spawned from that chance meeting in a hallway of the New Orleans Convention Center.

Recent studies have shown that online learning is not as effective or accepted as in-person courses for students at all levels of education. ${ }^{15-17}$ Bettinger and colleagues ${ }^{17}$ reported that taking college classes online reduced student grades by 0.44 points on the traditional 4-point scale. Furthermore, taking a prerequisite course online led to a 0.32 grade reduction the next term, even if the secondary class was in-person. The negative effects of online course taking were most profound in low-performing students. Students who routinely fell below the median experienced grade reductions of 0.5 to 0.8 points in most classes. Students who struggle, struggle more online. These finding provide evidence that students not only earned lower grades in online classes, but also learned less in the online setting. Susanna Loeb, a leading education expert from Brown University, recently summed up these findings and concluded, "Online courses are not as effective as in-person classes, but they are certainly better than no classes." ${ }^{18}$ If one extrapolates these educational policy expert's findings to postgraduate continuing medical education, the only conclusion is that the in-person cardiothoracic surgical conference should not disappear. However, if such in-person educational offerings are not available, as was the case during the pandemics that have bookend the 102-year history of the AATS, virtual conferencing must fill the gap.

\section{References}

1. Moon MR, Jones DR, Adams DH, Starnes VA. American Association for Thoracic Surgery: maintaining the mission during the coronavirus disease 2019 (COVID-19) pandemic. J Thorac Cardiovasc Surg. 2020;160:737-9.

2. Moon MR, Schaff HV, Maloney WT. History of The Journal of Thoracic and Cardiovascular Surgery. J Thorac Cardiovasc Surg. 2017;153:1225-30.

3. Bakaeen FG, Gillinov AM, Roselli EE, Chikwe J, Moon MR, Adams DH, et al. Cardiac surgery and the coronavirus disease 2019 pandemic: what we know, what we do not know, and what we need to do. J Thorac Cardiovasc Surg. 2020;160: 722-6.

4. Ad N, Luc JGY, Nguyen TC, COVID-19 North American Cardiac Surgery Survey Working Group. Cardiac surgery in North America and coronavirus disease 2019 (COVID-19): regional variability in burden and impact. J Thorac Cardiovasc Surg. July 20, 2020 [Epub ahead of print].

5. Iribarne A, Thourani VH, Cleveland JC, Malaisrie SC, Romano MA, Moon MR, et al. Cardiac surgery considerations and lessons learned during the COVID-19 pandemic. J Card Surg. 2020;35:1979-87.

6. Vervoort D, Dearani JA, Starnes VA, Thourani VH, Nguyen TC. Brave New World: virtual conferencing and surgical education in the Coronavirus Disease 2019 era. J Thorac Cardiovasc Surg. 2021;161:748-52.

7. AATS 100th Annual Meeting: A virtual learning experience. Available at: https:// www.aats.org/aatsimis/AATSEvent. Accessed August 23, 2020.

8. AATS virtual meeting expo. Available at: https://www.aats.org/aatsimis/ aatsevent/Expo_Hall. Accessed August 23, 2020.

9. Heinlein RA. The Moon Is a Harsh Mistress. New York, NY: GP Putnam's Sons: 1966:152.

10. Moon MR. In the Words of the Presidents: American Association for Thoracic Surgery. Beverly, MA: American Association for Thoracic Surgery; 2017.

11. Pitino R, Crawford E. The One-Day Contract: How to Add Value to Every Minute of Your Life. New York, NY: St Martin's Press; 2013.

12. Borst HG. Hands across the ocean: German-American relations in thoracic surgery. J Thorac Cardiovasc Surg. 1985;90:477-89.

13. Moon MR. \#WeAllNeedToChange. Ann Thorac Surg. 2020;109:996-8.

14. Holtz LL. Reflections on leadership. Available at: https://stsa.org/65thannual/ or https://www.youtube.com/watch?v=TNwEcViUYRQ\&feature=youtu.be. Accessed August 24, 2020.

15. Ahn J, McEachin AJ. Student enrollment patterns and achievement in Ohio's online charter schools. Educ Res. 2017;46:44-57.

16. Heppen JB, Sorensen N, Allensworth E, Walters K, Rickles J, Taylo SS, et al. The struggle to pass algebra: online vs. face-to-face credit recovery for at-risk urban students. J Res Educ Effectiveness. 2017;10:272-96.

17. Bettinger EP, Fox L, Loeb S, Taylor ES. Virtual classrooms: how online college courses affect student success. Am Econ Re. 2017;107:2855-75.

18. Loeb S. How effective is online learning? Education Week. 2020;39:17. 